\title{
Efficacy of condensed tannin presents in acacia extract on the control of Trichostrongylus colubriformis in sheep
}

\author{
Eficácia dos taninos condensados presentes no extrato de acácia no controle de \\ Trichostrongylus colubriformis em ovinos
}

\author{
Alessandro Pelegrine Minho ${ }^{I^{*}}$ Laerte Francisco Filippsen $^{\mathrm{I}}$ \\ Alessandro Francisco Talamine do Amarante ${ }^{\text {II }}$ Adibe Luiz Abdalla ${ }^{\text {III }}$
}

\begin{abstract}
The aim of this study was to evaluate the potential uses of acacia extract (AE) on Trichostrongylus colubriformis control in sheep. The lambs were allocated in three groups of six animals. Two groups were experimentally infected with thirdstage larvae of T. colubriformis and one was remained as noninfected control. Thirty days post-infection, the infected animals from treated group were supplemented with AE. During and after the treatment, the values of faecal eggs counts (FEC), number of third-stage larvae recovered per gram of faeces (LPG), number of FEC accumulated per animal during the treatment period, nematode egg viability, and worm burden were determined. Animals from non-infected group did not presented FEC values, during the experimental period. The average of total accumulated amount of FEC output per group, during the 10 days of the treatment was lower in $A E$ treated lambs $(P<0.05)$. The values of egg viability were statistically reduced $(P<0.05)$ on days 4,7 and 10 post treatment (p.t.). The number of LPG was lower $(P<0.05)$, at the days 10 and 14 p.t., in treated animals. AE showed potential to be used on the prophylaxis of gastrointestinal nematode infections in sheep.
\end{abstract}

Key words: sheep, tannins, nematodes, egg count.

\section{RESUMO}

O objetivo deste trabalho foi avaliar o potencial do extrato de acácia (EA) para o controle de T. colubriformis em ovinos. Os cordeiros foram alocados em três grupos de seis animais. Dois grupos foram experimentalmente infectados com larvas infectantes de T. colubriformis, sendo um grupo mantido como controle não infectado. Trinta dias pós-infecção, os animais infectados do grupo tratado foram suplementados com EA. Durante e após o tratamento os valores de contagem de ovos por grama de fezes (OPG), número de larvas de terceiro estágio por grama de fezes (LPG), número de OPG eliminado por animal durante o período de tratamento, viabilidade dos ovos e carga parasitária foram determinados. Os animais do grupo não infectado permaneceram com número de OPG igual a zero durante todo o período experimental. A média do número de OPG total eliminado por grupo, somatória durante os 10 dias de tratamento, foi menor nos cordeiros tratados com EA $(P<0,05)$. Os valores de viabilidade dos ovos de helmintos foram menores $(P<0,05)$ nos dias 4,7 e 10 póstratamento (p.t.). O número de LPG foi menor $(P<0,05)$, nos dias 10 e 14p.t., no grupo tratado. O EA demonstrou potencial para sua utilização no controle de T. colubriformis em ovinos.

Palavras-chave: ovinos, taninos, nematóides, contagem de ovos.

\section{INTRODUCTION}

With the increase in reports about helminthes strains resistant to chemical anthelmintics, some plant secondary metabolites (PSM) have been tested and evaluated for verification of its potential in the gastrointestinal nematodes control in ruminants. The tanning bark is a PSM studied worldwide, which causes deleterious effect in monogastric animals, and however, in ruminants, depending on the dose used, it presents anthelmintic effects on in vivo and in vitro assays.

Condensed tannins (CT) are PSM that comprise the most widespread class of tannin in nature

IÁrea de Sanidade Animal, Instituto Agronômico do Paraná (IAPAR), CP 481, 86001-970, Londrina, PR, Brasil. E-mail apminho@hotmail.com.*Autor para correspondência.

IInstituto de Biociências, Universidade Estadual Paulista (UNESP), Botucatu, SP, Brasil.

IIILaboratório de Nutrição Animal, Centro de Energia Nuclear na Agricultura (CENA), Universidade de São Paulo (USP), Piracicaba, SP, Brasil. 
(MANGAN, 1988), which exist as oligomers of flavan3-ols (catechin) or flavan-3,4-diols (epicatechin), and those occurring in temperate forages have a relative molecular mass of 2,000 to 4,000 comprising 10 to 12 oligomers of CT (FOO et al., 1982).

Recent surveys have identified anthelmintic effects from many bioactive substances (GITHIORI et al., 2006), particularly from CT sources (MINHO et al., 2008 a ; 2008b). Tannins are part of a group of polyphenol substances that contain factors affecting food taste and protein availability.

NIEZEN et al. (1995) also found a reduction in egg output in sheep fed with plants rich in tannins. The same was reported by NIEZEN et al. (1998) in sheep kept on pasture containing forages with medium levels of condensed tannins, which were more resistant to parasitism than those reared on pasture without condensed tannins. In these types of experiments, with continuous pasture which forages contains different levels of condensed tannins, there is an overlap of their mode of action, because they can act directly on the parasite and indirectly on host nutrition, effects that cannot be separated.

ATHANASIADOU \& KYRIAZAKIS (2004) reported that the concentration of these bioactive metabolites could vary between different regions, seasons of the year and even within the same grazing period. Moreover, CT analysis is complicated by the diversity of structures found within this group of compounds (polymers of flavonol units). Some of the advantages of their presence in the plant include protection against predators (insects, birds and herbivores), nematodes, fungi and bacteria, among others.

The aim of the present study was to investigate the potential anthelmintic effects of condensed tannins from acacia extract administered to sheep experimentally infected with Trichostrongylus colubriformis, mixed in dry molasses.

\section{MATERIAL AND METHODS}

\section{Local and Animals}

Eighteen four-month-old worm-free Santa Inês lambs were allocated in three groups. Initially all animals received anthelmintic drugs, for two consecutive days, a combination of Levamizole Phosphate (20 $\left.\mathrm{m} \mathrm{kg}^{-1}\right)$ and albendazole $\left(20 \mathrm{mg} \mathrm{kg}^{-1}\right)$ was administrated to confirm the worm-free status. A week after anthelmintic treatment, twelve animals were experimentally infected with 20,000 L3 of $\boldsymbol{T}$. colubriformis and six were kept as non-infected control. Group I (GI) was the non-infected control; group II (GII) was infected control and group III (GIII) was infected and supplied with condensed tannin (CT) source. Animals were also weighed weekly.

Feeding and condensed tannins source

All animals were kept housed indoorsfeeding hay and concentrate (diet with $13 \%$ of crude protein) and supplemented with a mineral salt ad libitum. The tannin source was the acacia extract (AE) from Acacia mearnsii (pure extract commercially available for the industry: tannery and manufacturing companies) and the values of CT were determined according HCl-Butanol method (PORTER et al., 1985). AE contains $15 \%$ of $\mathrm{CT}$. The total amount of CT offered to animals reached about $7.2 \mathrm{~g}$ per animal daily, considering values estimated to an animal with $30 \mathrm{~kg}$ of live weight (LW) since there were no leftovers of the concentrate diet after $24 \mathrm{~h}$, during the experimental period.

\section{Parasitological analysis}

Thirty days post-infection (p.i.), Group III was supplemented with $\mathrm{AE}$ ( $1.6 \mathrm{~g} \mathrm{~kg}^{-1}$ of body weight) per day added to concentrate, during 10 days. The same amount (1.6 $\mathrm{g} \mathrm{kg}^{-1}$ of B.W.) of dry molasses (DM) was mixture with the AE to improve the diet palatability. Animals from Group II were supplemented only with DM in the same dose of GIII.

\section{Slaughter procedures}

The animals underwent a 24 hour fast before slaughter, receiving only water. Immediately after the sacrifice, the small intestine were tied to avoid the movement of content between parts, and put into identified plastic bags and taken to the laboratory. During the parasitological necropsy, the gut was separated and opened, the content removed and mucosa washed and crashed for worm recovery. A 10\% volume aliquot was taken in duplicate from the small intestine. Formalin at $10 \%$ was added to this material for later worm identification and counting. Both aliquots were analyzed and the mean values of worm burden were used in statistical analysis.

Faeces analysis

The faeces samples were collected directly from the rectal ampoule to determine the faecal egg counts (FEC) using the modified McMaster technique (UENO \& GONÇALVES, 1998). FEC analysis were carried out weekly until day 21 p.i.; twice a week from day 21 to 30p.i.; and in alternated days during and after the treatment with CT (from day 30 to 45p.i.). During the week of AE evaluation, five fecal cultures and egg 
viability tests were carried out for each infected group (days: 0, 4, 7, 10 and 14 of CT treatments). Faecal cultures were made in small containers for 7 days at $27^{\circ} \mathrm{C}$ in a controlled temperature chamber (ROBERTS \& O'SULLIVAN, 1950). The egg hatch test (EHT) or egg viability test was carried out according to World Association for the Advancement of Veterinary Parasitology (WAAVP) recommendations, as described by COLES et al. (1992). For this, nematode eggs from faeces were recovered by using differential sieving through three stacked sieves with apertures of 250 , 100 and $25 \mu \mathrm{m}$, respectively. The material retained on the $25 \mu \mathrm{m}$ sieve was washed with water, sedimentated, and flotated with saturated sodium chloride followed by washing over a $20 \mu \mathrm{m}$ sieve with water; the eggs were subsequently used for EHT tests.

Cultures of faeces and EHT assays were carried out in specific days in order to allow the estimation of the number of infective larvae (L3) produced per gram of faeces (LPG) and the number of L1 hatched from eggs (egg viability percentage).

\section{Statistical methods}

The experimental design was fully randomized design with two treatments (with and without tannin) and six repetitions. The values of FEC, LPG, egg viability, number of FEC accumulated per animal during the treatment period, number of viable eggs released, and worm burden were analyzed using the general linear model (GLM) with repeated measurements procedure of SAS (1996). The means were compared by Duncan test and the differences between means with $\mathrm{P}<0.05$ were considered statistically different. The FEC number and worm count were previous transformed by $\log _{10}(\mathrm{x}+10)$.

\section{RESULTS}

Faecal egg counts and live weight

Animals from non-infected group did not presented FEC values, during the experimental period. Values of FEC from infected groups during the experimental period are demonstrated on figure 1. On day 32 p.i. (second day of treatment with AE) a significant reduction on FEC $(\mathrm{P}<0.05)$ was detected in GIII when compared with GII. From day 30p.i. to 45 p.i. the total accumulated amount of FEC released per animal. Comparing the two groups, the group that received $\mathrm{AE}$ showed significant reduction in total amount of FEC released $(\mathrm{P}<0.05)$ during this period, with average per animal of 11500 and 5317, respectively, for GII and GIII. Difference of LW and carcass weight of the sheep on this experiment was not significant $(\mathrm{P}>0.05)$. Mean values are shown in figure 2 .

The values of egg viability, analyzed on days $0,4,7,10$ and 14 post-treatment (p.t.), were statistically reduced $(\mathrm{P}<0.05)$ on days 4,7 and 10 post treatment (p.t.) in GIII when compared with GII (Table 1).

The number of L3 recovered per gram of faeces (LPG) was lower $(\mathrm{P}<0.05)$, at the days 10 and 14p.t., in Group III (Table 1). The use of CT source from $\mathrm{AE}$ on diet showed no significant influence on total worm burden $(\mathrm{P}>0.05)$, with mean values of 1860 (1001 female; 859 male) and 1470 ( 730 female; 740 male) for non-treated and treated group, respectively.

\section{DISCUSSION}

In the present study, animals receiving CT from $\mathrm{AE}$ eliminated less nematodes eggs on day 32 p.i., when compared with infected animal non-treated with

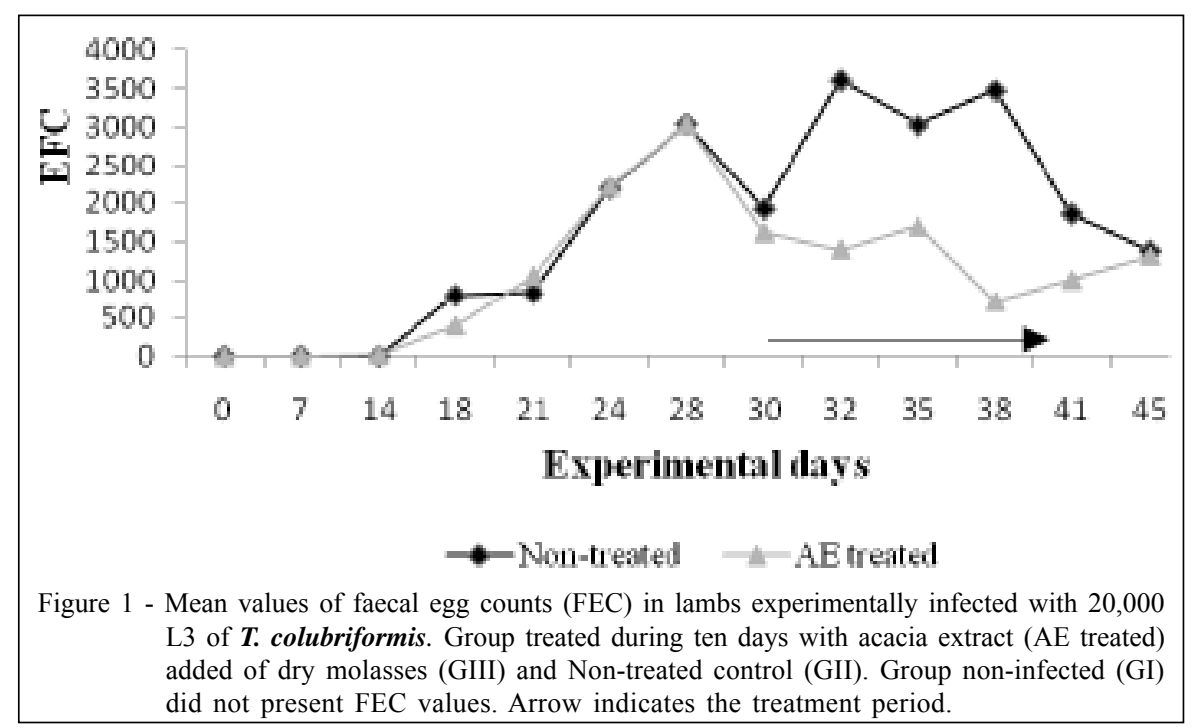

Ciência Rural, v.40, n.6, jun, 2010. 


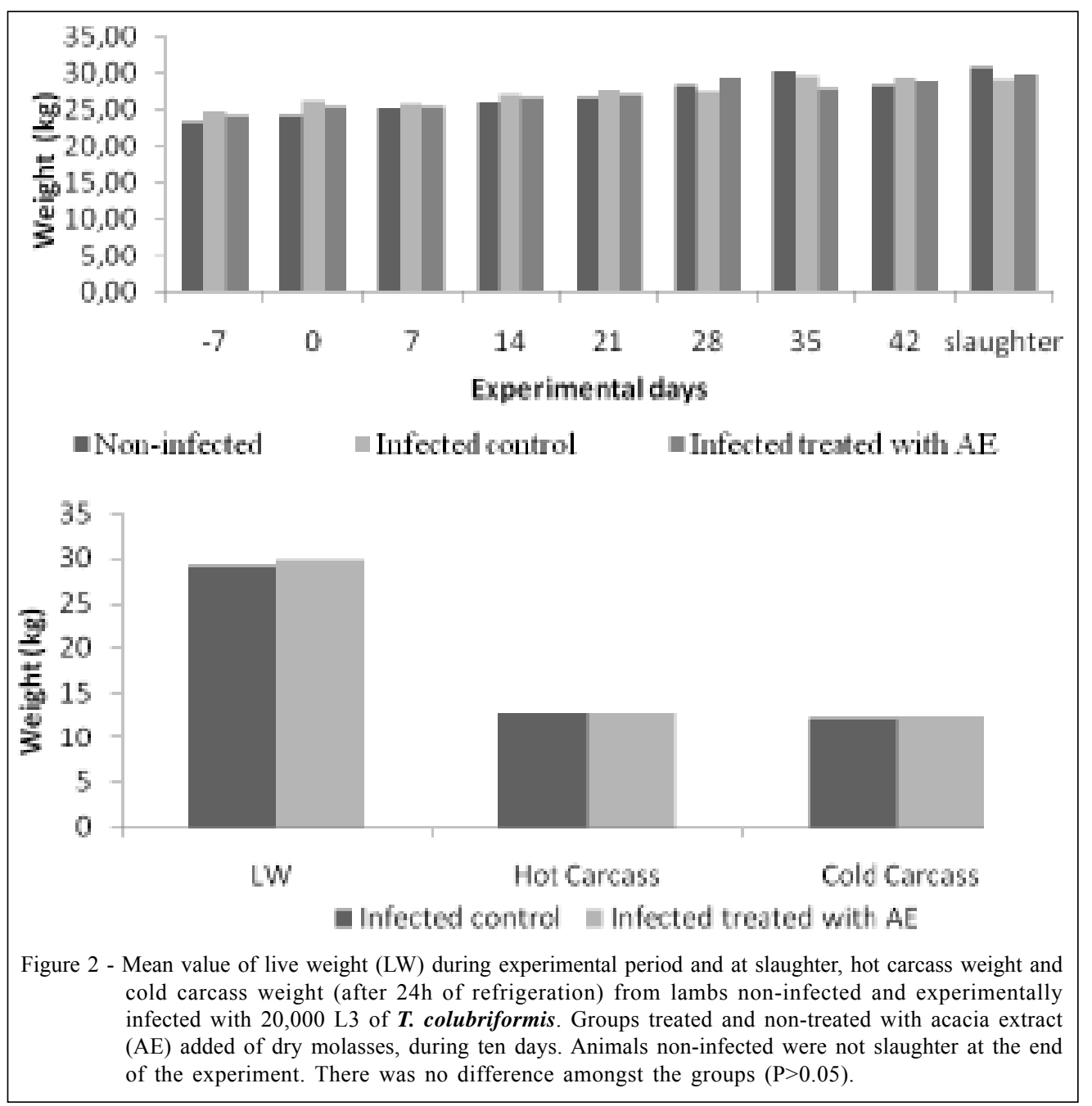

AE. Moreover, a reduction on total egg output was detected, during and after the treatment period, better demonstrated by the FEC averages, per animal, during that time which reached 11500 and 5317, respectively for infected animals from non-treated and treated group. This also means lower pasture contamination, which should be taken into account when developing strategies for control of parasitic gastroenteritis in sheep.

In agreement with our results, BUTTER et al. (2000) suggested that CT from QE had a direct anthelmintic action on T. colubriformis in sheep. CENCI et al. (2008), in sheep drenched with AE (3.2g $\mathrm{CT} /$ animal once week for 13 weeks), reported that $\mathrm{CT}$ also had direct action on the parasites studied $(\boldsymbol{H}$. contortus, T. colubriformis and Cooperia spp.). There are many reports of ovine nematode control based on CT using, including T. colubriformis (ATHANASIADOU et al., 2000a/2000b) and $\boldsymbol{H}$. contortus (NIEZEN et al., 2002a;
MINHO et al., 2008b). However, actually, the alternative parasite control based on tannins supplementation has a boarding aim focused on reduction of chemical products usage in the flock, increasing the interval between anthelmintic administration and, primordially, reducing the selective pressure on parasites strains caused by the high frequency of drenches with the traditional antiparasitic drugs.

Unfortunately, worm burden reduction was not detected, however the reduction recorded in FEC associated with reduction in egg vialability, indicates that the treatment with CT can result in considerably reduction in pasture contamination by L3. Similarly, IQBAL et al. (2007) affirmed that both direct and indirect effects of CT are beneficial in lowering the contamination of pasture by reducing the hatchability of nematode eggs and faecal egg count reduction.

The direct effect of CT on T. colubriformis eggs and infective larvae were clearly evidenced in the 
Table 1 - Number of third stage larvae per gram of faeces (LPG) and egg viability (percentage of first stage larvae identified after 24h L1\%) in faecal samples collected from lambs experimentally infected with Trichostrongylus colubriformis. Groups non-treated (GII) and treated with acacia extract, during 10 days (GIII). Group non-infected (GI) did not present FEC values.

\begin{tabular}{|c|c|c|c|c|c|c|c|c|c|c|}
\hline \multirow[t]{2}{*}{ Groups } & \multicolumn{2}{|c|}{----------0---------- } & \multicolumn{2}{|c|}{----------4----------- } & \multicolumn{2}{|c|}{----------7---------- } & \multicolumn{2}{|c|}{---------10--------- } & \multicolumn{2}{|c|}{---------14-------- } \\
\hline & LPG & L1 \% & LPG & L1 \% & LPG & L1 \% & LPG & L1 \% & LPG & L1 \% \\
\hline G II & $5790^{\mathrm{a}}$ & $71^{\mathrm{a}}$ & $15690^{\mathrm{a}}$ & $90,5^{\text {a }}$ & $5340^{\mathrm{a}}$ & $71,5^{\mathrm{a}}$ & $1170^{\mathrm{a}}$ & $31,5^{\mathrm{a}}$ & $47400^{\mathrm{a}}$ & $98,5^{\mathrm{a}}$ \\
\hline G III & $11910^{\mathrm{a}}$ & $70^{\mathrm{a}}$ & $3900^{\mathrm{a}}$ & $9,5^{\mathrm{b}}$ & $1830^{\mathrm{a}}$ & $54,5^{\mathrm{b}}$ & $0^{\mathrm{b}}$ & $3^{b}$ & $900^{\mathrm{b}}$ & $59,50^{\mathrm{a}}$ \\
\hline
\end{tabular}

Different letter on the same column $\mathrm{P}<0.05$.

current research. These results corroborate with MINHO et al. (2008b) who analyzed the AE efficacy on in vitro studies (larvae feed inhibition) and had demonstrated differences between the aqueous water control and CT treated groups $(\mathrm{P}<0.01)$. The LD50 values were $0.043,0.038$ and $0.050(\mathrm{SE}=0.0024)$, for Haemonchus contortus, Trichostrongylus vitrinus and Teladorsagia circumcincta, respectively. Analysis of these experiments suggested that the direct effect of CT on first larvae stage of those parasites could be used as an alternative means for controlling nematodes in sheep.

\section{CONCLUSION}

The use of CT from AE to promote $\boldsymbol{T}$. colubriformis control in sheep can be indicated only in prophylactic controls, reducing the pasture contamination and the nematode reinfection in sheep.

\section{ACKNOWLEDGEMENTS}

The authors are grateful for the financial support from National Counsel of Technological and Scientific Development $(\mathrm{CNPq})$ and Agronomic Institute of Paraná (IAPAR).

\section{ETHICAL APPROVAL}

This experiment was approved by the Animal Experimentation Ethics Committee of the Nuclear Energy Center for Agriculture (CENA), São Paulo University (USP), Brazil - number 001/2007.

\section{REFERENCES}

ATHANASIADOU, S. et al. Consequences of long-term feeding with condensed tannins on sheep parasitized with Trichostrongylus colubriformis. International Journal for Parasitology, v.30, p.1025-1033, 2000a. Available from: <http://www.sciencedirect.com/ science?_ob=ArticleURL\&_udi=B6T7F-414NX0BB \& use r $=10 \&$ coverDate $=08 \% 2$ F $31 \% 2$ F 2000 \&_rdoc $=1 \&$ f $\mathrm{m}_{\mathrm{t}}=\mathrm{high} \&$ _orig=browse \&_sort $=$ 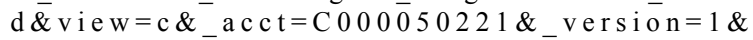
_urlVersion=0\&_userid=10\&md5=051b77fabe7f76bbae $00828 \mathrm{a} 033 \mathrm{c} 9 \mathrm{ea}>$. Accessed: Apr. 20, 2010. doi: 10.1016/S0020-7519(00)00083-7.

ATHANASIADOU, S. et al. Effects of short-term exposure to condensed tannins on adult Trichostrongylus colubriformis. Veterinary Record, v.146, p.728-732, 2000b. Available from: $<$ http://veterinaryrecord.bvapublications.com/cgi/content/ abstract $/ 146 / 25 / 728$ ? maxtoshow $=$ \&hits $=10$ \&RESULTFORMA $\mathrm{T}=\&$ a u t h or $1=\mathrm{ath}$ a n a s i a d o u \& a ndore $\mathrm{x}$ actfulltext $=$ and \&searchid $=1 \&$ FIRSTINDEX $=0 \&$ sortspec $=$ re levance $\&$ volume $=146 \&$ resourcetype $=$ HWCIT $>$. Accessed: Apr. 20, 2010. doi: 10.1016/S0921-4488(03)00204-9.

ATHANASIADOU, S.; KYRIAZAKIS, I. Plant secondary metabolites: antiparasitic effects and their role in ruminant production system. Proceedings of Nutrition Society, v.63, p.631-639, 2004. Available from: <http://journals.cambridge.org/ a c t i o n / d i sp 1 a y F u 11 t ext ? t y pe $=6 \&$ f i $\mathrm{d}=902256 \& \mathrm{jid}=\&$ volumeId $=\&$ issueId $=\&$ aid $=902252>$. Accessed: Apr. 20, 2010. doi: 10.1079/PNS2004396.

BUTTER, N.L. et al. Effect of dietary tannin and protein concentration on nematode infection (Trichostrongylus colubriformis) in lambs. Journal of Agricultural Science, v.134, p.89-99, 2000. Available from: <http://journals.cambridge.org/action/ displayAbstract?fromPage $=$ online $\&$ aid $=7553>$. Accessed: Apr. 20, 2010. doi: $10.1017 / \mathrm{S} 0021859699007315$.

CENCI, F.B. et al. Effects of condensed tannin from Acacia mearnsii on sheep infected naturally with gastrointestinal helminthes. Veterinary Parasitology, v.144, p.132-137, 2008. Available from: <http://www.sciencedirect.com/ science?_ob=ArticleURL\&_udi=B6TD7-4M69JVW$2 \&$ user $=10 \&$ \& overDate $=03 \% 2$ F $15 \% 2$ F $2007 \&$ _rdoc $=1 \&$ fmt $=\bar{h}$ igh\&_orig=browse\&_sort $=\mathrm{d} \&$ view $=$ $\mathrm{c} \&$ _acct $=\mathrm{C} 000050221 \&$ \&version $=1 \&$ \&urlVersion $=0 \&$ userid=10\&md5=7a3df7f1 f0a426a6f65b3b3a89515e 01>. Accessed: Apr. 20, 2010. doi: 10.1016/j.vetpar.2006.09.021.

COLES, G. et al. World Association for the Advancement of Veterinary Parasitology (W.A.A.V.P.) methods for the detection of anthelmintic resistance in nematodes of veterinary importance. Veterinary Parasitology, v.44, p.35-44, 1992. Available from: $<\mathrm{h} \mathrm{t} \mathrm{t} \mathrm{p} \mathrm{:} \mathrm{/} \mathrm{/} \mathrm{w} \mathrm{w} \mathrm{w.} \mathrm{s} \mathrm{c} \mathrm{i} \mathrm{e} \mathrm{n} \mathrm{c} \mathrm{e} \mathrm{d} \mathrm{i} \mathrm{r} \mathrm{e} \mathrm{c} \mathrm{t} \mathrm{.} \mathrm{c} \mathrm{o} \mathrm{m/}$ science?_ob=ArticleURL\&_udi=B6TD7-476MR61$\mathrm{X} \mathrm{N} \& \quad$ u s e r $=10 \& \quad$ c o v e r D a t e $=09 \% 2$ F $30 \% 2$ F $1992 \&$ \& d o c $=1 \&$ \& f t $^{2}=\mathrm{high}$ $\&_{-}$orig $=$browse $\&$ _sort $=\mathrm{d} \& \mathrm{view}=\mathrm{c} \& \&_{\text {a }} \mathrm{acct}=$ C $000050221 \&_{\text {_version }} 1 \&_{\text {_ ur } 1 \text { Version }}$ 
0\&_userid $=10 \& \mathrm{md} 5=53 \mathrm{cddf} 3 \mathrm{af} 77 \mathrm{fb} 4725 \mathrm{~d} 268796 \mathrm{~b} 407 \mathrm{fc} 4 \mathrm{a}>$. Accessed: Apr. 20, 2010. doi: 10.1016/0304-4017(92)90141-U.

FOO, L.Y. et al. Proanthocyanidin polymers of fodder legumes. Phytochemistry, v.21, p.933-935, 1982. Available from: <http:/ / w w w . $\mathrm{s}$ c i e $\mathrm{n} \mathrm{c}$ e d i $\mathrm{r}$ e c t. c o m science? ob=ArticleURL\&_udi=B6TH7-42HXF75$49 \&$ u s e r $=10 \&$ c ove $\mathrm{r}$ D a t e $=12 \% 2$ F $31 \% 2$ F 1982\&_rdoc $=1 \&$ fmt $=$ high\&_orig $=$ browse \&_sort $=$ $\mathrm{d} \& \mathrm{vi}$ e $\overline{\mathrm{w}}=\mathrm{c} \&$ \& a c c t $=\mathrm{C} 0000500221 \&$ \& e r s i o n $=1$ $\&$ u r 1 Version $=0 \&$ u s e r i d $=10 \&$ m d $5=$ a 4 606̈6eb42830cc4793dc277e9156062>. Accessed: Apr. 20, 2010. doi: 10.1016/0031-9422(82)80096-4.

GITHIORI, J.B. et al. Use of plants in novel approaches for control of gastrointestinal helminths in livestock with emphasis on small ruminants. Veterinary Parasitology, v.139, p.308320, 2006. Available from: <http://www.sciencedirect.com/ science? $o b=$ ArticleURL\& udi=B6TD7-4K1HDY9$3 \&$ user $=10 \&$ coverDate $=07 \% 2$ F $31 \% 2$ F $2006 \&$ rdoc 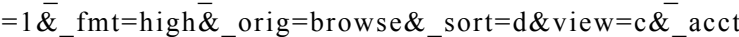 $=\mathrm{C} 000050221 \&$ version $=1 \&$ urlVersion $=0 \&$ user $\mathrm{id}=10 \& \mathrm{md} 5=767 \mathrm{fe} \overline{\mathrm{d}} 1 \mathrm{f} 0 \mathrm{~b} 655 \mathrm{edcdbdac} 5 \mathrm{f} 1 \mathrm{cf} 7 \mathrm{c} 8 \mathrm{cff}>$. Accessed: Apr. 20, 2010. doi: 10.1016/j.vetpar.2006.04.021.

IQBAL, Z. et al. Direct and indirect anthelmintic effects of condensed tannins in sheep. Veterinary Parasitology, v.144, n.1-2, p.125131, 2007. Available from: <http://www.sciencedirect.com/ science? ob=ArticleURL \& udi=B6TD7-4MBC58V$3 \&$ user $=10 \&$ coverDate $=03 \% 2$ F $15 \% 2$ F $2007 \&$ rdoc $=$ $1 \&$ fmt $=$ high \&_orig $=$ browse \&_sort $=$ d \& view $=$ c $\&$ _a $\mathrm{cct}=\mathrm{C} 000050 \overline{2} 21 \&$ versio $\bar{n}=1 \&$ urlVersion $=$ $0 \&$ userid $=10 \& \mathrm{md} 5=\mathrm{bdb} 117770 \mathrm{ec} 50 \mathrm{c} 9745805969189682 \mathrm{~d} 0>$. Accessed: Apr. 20, 2010. doi: 10.1016/j.vetpar.2006.09.035.

MINHO, A.P. et al. Effect of Acacia molissima tannin extract on the control of gastrointestinal parasites in sheep. Animal Feed Science and Technology, v.147, n.1-3, p.172-181, 2008a. Available from: <http://www.sciencedirect.com/ science?_ob=ArticleURL\&_udi=B6T42-4PYRKCS$5 \&$ use $\bar{r}=10 \&$ coverDate $=11 \% 2$ F $14 \% 2$ F $2008 \&$ _rdoc $=1 \&$ \& fmt $=\overline{h i g h} \&$ _orig $=$ browse \&_sort $=\mathrm{d} \& \mathrm{view}=\mathrm{c}$ 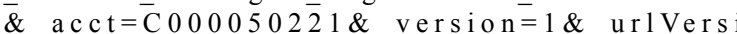 on $=0 \&$ userid $=10 \& \mathrm{md} 5=1 \mathrm{c} 81340 \overline{\mathrm{c}} 156305 \mathrm{f} 626912 \mathrm{efce} 7 \mathrm{a} 57 \mathrm{fb} 5>$. Accessed: Apr. 20, 2010. doi: 10.1016/j.anifeedsci.2007.09.016.

MINHO, A.P. et al. In vitro effect of condensed tannin extract from acacia (Acacia mearnsii) on gastrointestinal nematodes of sheep. Brazilian Journal of Veterinary Parasitology, v.17, n.1, p.144-148, 2008b. Available from: <http:// www.cbpv.com.br/rbpv/documentos/17supl.12008/ Helmintol011.pdf>. Accessed: Apr. 20, 2010.

NIEZEN, J.H. et al. Growth and gastrointestinal parasitism in lambs grazing on of seven herbages and dosed with larvae for six weeks. Journal of Agricultural Science, v.125, p.281289, 1995. Available from: <http://journals.cambridge.org/ action $/$ displayAbstract fromPage $=$ online $\&$ aid $=4821140>$. Accessed: Apr. 20, 2010. doi: 10.1017/S0021859600084422.

NIEZEN, J.H. et al. Production, fecal egg counts and worm burdens of ewe lambs which grazed six contrasting forages. Veterinary Parasitology, v.80, p.15-27, 1998. Available from: <http:// www.sciencedirect.com/science?_ob=ArticleURL\&_udi=B6TD73V7JG37-2\& user $=10 \&$ coverDate $=12 \% 2$ F $15 \% 2$ F $1998 \&$ n_rdoc $=1 \&$ \& $\mathrm{mt}=$ high \&_orig=browse \&_sort $=\mathrm{d} \&$ $\mathrm{v} \overline{\mathrm{i}} \mathrm{ew}=\mathrm{c} \&$ a $\mathrm{c} \mathrm{ct}=\mathrm{C} 000050221 \&$ \& version $=1 \&$ _ urlVersion $=0 \&$ userid $=10 \& \mathrm{md} 5=8 \mathrm{~b} 1 \mathrm{c} 0 \mathrm{cad} 72115 \mathrm{f} 21491 \mathrm{dccafcc} 9 \mathrm{f} 20 \mathrm{ec}>$. Accessed: Apr. 20, 2010. doi: 10.1016/S0304-4017(98)00202-7.

NIEZEN, J.H. et al. The effect of feeding sulla (Hedysarum coronarium) or lucerne (Medicago sativa) on lamb parasite burdens and development of immunity to gastrointestinal nematodes. Veterinary Parasitology, v.105, p.229-245, 2002. Available from: $<\mathrm{ht} \mathrm{t}$ p: / / w w w s c i e n c e d i r e t . c o m / science? ob=ArticleURL\& udi=B6TD7-458PB36$3 \&$ _user $=10 \&$ coverDate $=05 \% 2 \mathrm{~F} 02 \% 2 \mathrm{~F} 2002 \&$ rdoc $=1$ 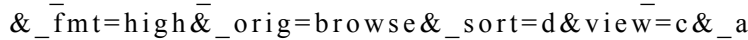 $\mathrm{cct}=\mathrm{C} 000050221 \&$ version $=1 \&$ urlversion $=0 \&$ userid $=10 \& \mathrm{md} 5=\mathrm{c} 93995 \mathrm{~b} 3355 \mathrm{e} 95 \mathrm{fdadaa} 32195 \mathrm{ea} 53862>$. Accessed: Apr. 20, 2010. doi: 10.1016/S0304-4017(02)00014-6.

NIEZEN, J.H. et al. The effect of diet fed to lamb on subsequent development of Trichostrongylus colubriformis larvae in vitro and on pasture. Veterinary Parasitology, v.105, n.4, p.269283, 2002. Available from: <http://www.sciencedirect.com/ science? ob=ArticleURL\& udi=B6TD7-45C02HR$4 \&$ user $=10 \&$ coverDate $=05 \% 2$ F $10 \% 2$ F $2002 \&$ rdo $\mathrm{c}=\overline{1} \&$ \& fm t $=$ h igh\&_orig $=$ browse \&_sort $=$ d \& vie $\mathrm{w}=\mathrm{c} \&$ acct $=\mathrm{C} 000050221 \& \quad$ version $=1 \&$ urlVers ion $=0 \&$ _userid $=10 \& \mathrm{md} 5=0 \mathrm{cf} 1 \mathrm{ebe} 19 \mathrm{~d} 8 \mathrm{f} 5 \mathrm{c} 04396 \mathrm{be} 07881 \mathrm{e} 526 \mathrm{cf}>$. Accessed: Apr. 20, 2010. doi: 10.1016/S0304-4017(02)00025-0.

PORTER, L.J. et al. The conversion of procyanidins and prodelphinidins to cyanidin and delphinidin. Phytochemistry, v.25, p.223-230, 1985. Available from: <http://www.sciencedirect.com/ science?_ob=ArticleURL\&_udi=B6TH7-42GFCYB$1 \mathrm{H} \&$ use r $=10 \&$ coverDate $=12 \% 2$ F $23 \% 2$ F 1985 \&_rdoc $=1 \&$ \&mt $=$ high\&_orig=browse\&_sort $=$ d \&vi $\mathrm{e} \overline{\mathrm{w}}=\mathrm{c} \& \quad$ a c c t $=\mathrm{C} 000050221 \& \quad$ version $=1 \&$ urlV ersion $=0 \&$ userid $=10 \& \mathrm{md} 5=5 \mathrm{~d} 19 \mathrm{~b} 2 \mathrm{e} 8 \mathrm{f} 3 \mathrm{~b} 434 \mathrm{bca} 884978 \mathrm{e} 16 \mathrm{~b} 692 \mathrm{~b} 9>$. Accessed: Apr. 20, 2010. doi: 10.1016/S0031-9422(00)94533-3.

ROBERTS, F.H.S.; O'SULLIVAN, J.P. Methods for egg counts and larval cultures for strongyles infesting the gastrointestinal tract of cattle. Australian Journal of Agriculture Research, v.1, p.99-102, 1950.

SAS Institute. Statistical Analysis System. User's guide. 4.ed. Cary, 1996. 890p.

UENO, H.; GONÇALVES, P.C. Manual para diagnóstico das helmintoses de ruminantes. 4.ed. Tokyo: Japan International Cooperation Agency, 1998. 143p. 